\title{
MICROLAPAROSCOPY IN GYNECOLOGY: ANALYSIS OF 16 CASES AND REVIEW OF LITERATURE
}

Fabio Ikeda, Maurício Simões Abrão, Sérgio Podgaec, Alexandre Pupo Nogueira, Rosa Maria Neme and José Aristodemo Pinotti

IKEDA F et al. - Microlaparoscopy in gynecology: analysis of 16 cases and review of literature. Rev. Hosp. Clín. Fac. Med. S. Paulo 56(4):115-118, 2001.

Microlaparoscopy represents the development of endoscopic surgery towards a minimally invasive surgical procedure. The advantages include fewer surgical complications, faster return to daily activities, more comfortable postoperative recovery, and satisfactory aesthetic results. The possibility of performing surgery under sedation may result in shorter hospitalization, lower hospital costs, and easier anesthetic procedures.

The authors report their preliminary experience with the use of microlaparoscopy, using optics and $2 \mathrm{~mm}$ instruments, as well as a review of the literature since the introduction of this new technique. The report of these 16 cases demonstrates that microlaparoscopy is a feasible technique with satisfactory results. On the other hand, this new technique requires precise indications and a training period for the development of the skills necessary for performing these surgeries.

DESCRIPTORS: Laparoscopy. Gynecology. Microsurgery. Surgical Procedures. Laparoscopic instruments.

Laparoscopy has been used since the beginning of the 20th century and became known as a diagnostic and therapeutic procedure in gynecology in the 1970s. In the 1980s with the coming of video-laparoscopy, it was much more widespread, offering more comfort during the surgery and more advanced procedures ${ }^{17}$. In the beginning of the 1990s, with the concept of minimally invasive surgery, a new technique, microlaparoscopy, started being developed using optics and instruments smaller than $5 \mathrm{~mm}$ in diameter ${ }^{18}$.

Dorsey \& $\mathrm{Tabb}^{8}$ and Risquez et al..$^{22}$ were the first to mention this endoscopic method ${ }^{8,22}$. However, these cases did not have the expected impact because of the poor quality of the image. Risquez et al. ${ }^{21}$, performed 30 microlaparoscopies obtaining an improvement of the image and presenting more indications for the use of this method $^{21}$.
At that time, technology had greatly improved, and the development of endoscopes with better fiber optics permitted clearer images with a scope of a smaller diameter. Therefore, it became possible to perform diagnostic laparoscopy and small treatments, such as cauterization of endometriosis foci, adhesiolysis, tubal sterilization, appendectomy, and assisted reproduction procedures, such as ZIFT (zygote intrafallopian transfer) and GIFT (gamete intrafallopian transfer $)^{4,7,9,11,23,24}$. Later, a microlaparoscopic hysterectomy was performed, demonstrating that this technique is feasible even for more complex procedures ${ }^{25}$.

From the Division of Gynecology, Hospital das Clínicas, Faculty of Medicine, University of São Paulo.
The main advantages obtained with the reduction in the caliber of the instruments are decrease in the surgical trauma and the patients' costs due to the shorter period of recovery ${ }^{1}$.

The aim of this study is to report 16 cases in which microlaparoscopy with diagnostic and therapeutic purpose was performed. These cases had satisfactory results and open promising perspectives for many different indications.

The first cases using sedation and local anesthesia were also analyzed, demonstrating benefits over general anesthesia.

\section{ANALYSIS OF 16 CASES}

The microlaparoscopy procedure was indicated in situations in which there was no possibility of removing large tissue samples from the abdominal cavity. The patients' ages ranged from 18 to 42 years. There was no as- 
sociated intercurrent factor for any of the patients.

Twelve female patients underwent general anesthesia with fentanyl $(5 \mu \mathrm{g} / \mathrm{kg})$, propofol $(2 \mathrm{mg} / \mathrm{kg})$ and atracurium $(0.4$ to $0.5 \mathrm{mg} / \mathrm{kg})$ following inhalation of isoflurane and subsequent orotracheal intubation. Four female patients underwent conscious sedation and local anesthesia with satisfactory results. These patients showed a normal body mass index with no suspicion of large pelvic adhesions. The sedation was administered using midazolam (5 to $10 \mathrm{mg}$ ) and fentanyl chloridrate $(2 \mu \mathrm{g} / \mathrm{kg})$, and using an additional $1 \mu \mathrm{g} / \mathrm{kg}$ as necessary.

In all the cases, local anesthesia was administered with infiltration of $5 \mathrm{~mL} 0.5 \%$ bupivacaine into the surgical sites and instillation of $40 \mathrm{~mL} 0.5 \%$ lidocaine over pelvic structures.

The surgery was performed with a 2-mm microfiberoptic microlaparoscope (Auto-Suture, United States Surgical Corporation, USA), which was introduced into the abdominal cavity with a $2 \mathrm{~mm}$ trocar, acting simultaneously as a Veress needle. Thus, before placing the pneumoperitoneum, the microlaparoscope may be introduced in the cavity to check correct position of the cannula in order to avoid the injection of carbonic gas erroneously into the pre-peritoneum.

The accessory punctures were performed with trocars similar to those described above, 2-mm or 5-mm in diameter when there was need to remove larger samples from the abdominal cavity. The 2-mm forceps used were made of titanium, offering adequate precision and satisfactory resistance. The pneumoperitoneum was maintained with intraabdominal pressure of $9 \mathrm{~mm} \mathrm{Hg}$.

A uterine manipulator was used in most of the cases, which was fundamental to providing an adequate exposition of the pelvic organs.

In 14 surgeries, the postoperative diagnostic was minimal or mild endometriosis, exposing a disease appropriately approached by microlaparoscopy. In 1 case, endometriosis was characterized as moderate (according to standards from the American Society for Reproductive Medicine, 1996) $)^{5}$ In all the cases, biopsy, resection, and cauterization of endometriosis foci were done. Salpingostomy for an ectopic pregnancy, myomectomy, and adhesiolysis were other performed surgeries.

Table 1 describes reported cases with more details.

\section{DISCUSSION}

Nowadays, after lengthy studies on microlaparoscopy, many authors have been using this new surgical approach, which has become a feasible new diagnostic and therapeutic option in selected cases.

In several studies, the diagnostic accuracy between the 2-mm and the $10-\mathrm{mm}$ telescope was the same $\mathrm{e}^{10,12,16}$. The patients described in this article were operated on with adequate images, and the performance of microlaparoscopy was a feasible technique (Fig.1). The endometriosis lesions that were the indications for most of the surgeries were easily identified, leaving no doubt about their presence.

The possibility of simplification of anesthesia in some cases of microlaparoscopy may bring interesting benefits, such as reduction in the hospitalization and postoperative pain. Bauer et al. ${ }^{6}$ studied the administration of microlaparoscopy procedures with sedation and local infiltration, listing the anesthetic methods.

The achieved results in our cases were satisfactory, emphasizing that the incidence of nausea was insignificant, and no orotracheal discomfort with se-

Table 1 - Analysis of 16 cases of microlaparoscopy.

\begin{tabular}{|c|c|c|c|c|c|c|c|}
\hline Age & Diagnosis & $\begin{array}{l}\text { Performed } \\
\text { surgery }\end{array}$ & $\begin{array}{l}\text { Surgery } \\
\text { time }\end{array}$ & $\begin{array}{l}\text { Number of } \\
2 \mathrm{~mm} \\
\text { punctures }\end{array}$ & $\begin{array}{l}\text { Number of } \\
5 \mathrm{~mm} \\
\text { punctures }\end{array}$ & Anesthesia & Hospitalization \\
\hline 35 years & EDT II & $\mathrm{R}+\mathrm{C}$ & $35 \mathrm{~min}$ & 3 & No & General & $12 \mathrm{~h}$ \\
\hline 42 years & EDT I + myoma & $\mathrm{R}+\mathrm{C}+\mathrm{M}$ & $45 \mathrm{~min}$ & 2 & 1 & General & $24 \mathrm{~h}$ \\
\hline 18 years & EDT I+HC & $\mathrm{R}+\mathrm{C}$ & $20 \mathrm{~min}$ & 3 & No & General & $12 \mathrm{~h}$ \\
\hline 36 years & EDT I & $\mathrm{R}+\mathrm{C}$ & $20 \mathrm{~min}$ & 3 & No & General & $12 \mathrm{~h}$ \\
\hline 38 years & EDT I & $\mathrm{R}+\mathrm{C}$ & $35 \mathrm{~min}$ & 3 & No & General & $24 \mathrm{~h}$ \\
\hline 41 years & EDT I & $\mathrm{R}+\mathrm{C}$ & $65 \mathrm{~min}$ & 2 & 1 & General & $24 \mathrm{~h}$ \\
\hline 41 years & EDT I & $\mathrm{R}+\mathrm{C}$ & $40 \mathrm{~min}$ & 2 & 1 & General & $24 \mathrm{~h}$ \\
\hline 35 years & EDT I+EP & $\mathrm{R}+\mathrm{C}+\mathrm{S}$ & $50 \mathrm{~min}$ & 2 & 1 & General & $12 \mathrm{~h}$ \\
\hline 28 years & EDT III & $\mathrm{R}+\mathrm{C}$ & $50 \mathrm{~min}$ & 2 & 1 & General & $24 \mathrm{~h}$ \\
\hline 26 years & EDT I & $\mathrm{R}+\mathrm{C}$ & $50 \mathrm{~min}$ & 3 & No & General & $12 \mathrm{~h}$ \\
\hline 34 years & Adhesions & Adhesiolysis & $50 \mathrm{~min}$ & 3 & No & Sedation & $4 \mathrm{~h}$ \\
\hline 31 years & EDT II & $\mathrm{R}+\mathrm{C}$ & $45 \mathrm{~min}$ & 3 & No & Sedation & $4 \mathrm{~h}$ \\
\hline 21 years & EDT I & $\mathrm{R}+\mathrm{C}$ & $40 \mathrm{~min}$ & 3 & No & Sedation & $4 \mathrm{~h}$ \\
\hline 18 years & EDT I & $\mathrm{R}+\mathrm{C}$ & $45 \mathrm{~min}$ & 4 & No & General & $12 \mathrm{~h}$ \\
\hline 28 years & EDT II & $\mathrm{R}+\mathrm{C}$ & $30 \mathrm{~min}$ & 3 & No & Sedation & $4 \mathrm{~h}$ \\
\hline 23 years & EDT II & $\mathrm{R}+\mathrm{C}$ & $35 \mathrm{~min}$ & 3 & No & General & $12 \mathrm{~h}$ \\
\hline
\end{tabular}

EDT: endometriosis; HC: hemorrhagic cyst; EP: ectopic pregnancy; R: endometriosis resection; C: endometriosis cauterization; M: myomectomy; S: salpingostomy 


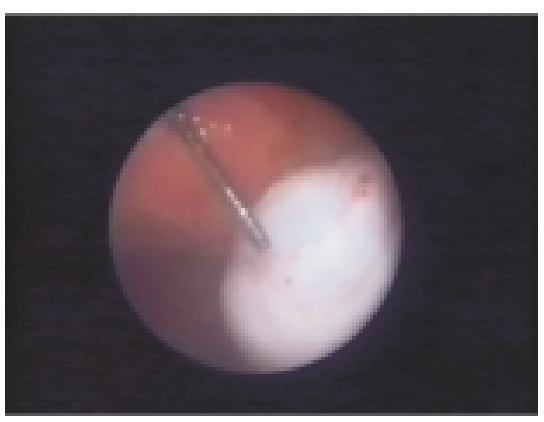

Figure 1 - Ovarian endometriosis approached by microlaparoscopy.

dation was observed. The adequate selection of the patients is fundamental. The surgery should be rapid and accurate because the patient is awake.

The reduction in the amount of carbonic gas used for the pneumoperitoneum was essential, because when the abdominal pressure was higher than $15-\mathrm{mm} \mathrm{Hg}$ or the carbonic gas volume was higher than 2,5 liters, patients experienced discomfort ${ }^{23}$.

The mean time of postoperative hospitalization was shorter for the patients that had received sedation (mean time 4 hours) compared with those who had received general anesthesia (mean time 17 hours).

The utilization of the uterine manipulator was essential to a satisfactory pelvic structure exposure. An auxiliary puncture was needed in a virgin patient, since this use was not possible.

In some cases, a diode laser was used, which was portable, easily managed, and adaptable to the 2-mm trocar. This innovation has brought more accuracy to the procedure, with desired benefits to these cases ${ }^{2}$.

The postoperative recovery was shorter with reduction of pain and abdominal discomfort than conventional laparoscopy.

The aesthetic results were adequate, with no need for skin suture. The incision was closed with adhesive tape. There was no report of postoperative infection.

The simplification of the anesthesia allowed the intervention to be done in an ambulatory surgery center. However, there are still doubts whether it can be performed in a gynecologist office.

Palter \& Olive in 1996 and Almeida \& Val-Gallas in 1998 performed office microlaparoscopies ${ }^{3,19}$. These authors recommend this technique to patients with chronic pelvic pain, and it may be performed with local anesthesia and light conscious sedation. However, some authors do not agree with office microlaparoscopy and suggest an ambulatory surgical room for these procedures ${ }^{11}$.

Analyzing the postoperative pain, a minor incidence of abdominal and scapular pain has been reported, as well as the necessity for analgesics in microlaparoscopy ${ }^{14}$. Abdominal instillation and local infiltration of anesthetics have benefited the patients ${ }^{13,20}$. This procedure was performed in all the cases reported in this paper.

Risquez et al. ${ }^{23}$ published a multicentric report of 408 cases, the biggest study of this technique. The patients were divided into 3 groups according to the type of anesthesia. The first group received only local anesthesia and oral diazepam; the second, sedation and local anesthesia; and the third, general anesthesia without orotracheal intubation. From this work, we conclude that microlaparoscopy is effective as a diagnostic technique and for some therapeutic procedures, such as adhesiolysis, endometriosis cauterization, embryo transfer, and salpingostomy. The most satisfactory anesthetic technique depends on the characteristics of each patient.

Another possible innovation with this method is conscious pain mapping, where the patient helps the surgeon localize the painful areas, making it possible to perform appendectomy by mapping ${ }^{4}$. In patients without pelvic diseases, some areas are painful when touched, extended, or compressed. Thus, the stretching of the fallopian tube or of the utero-ovarian ligament caused a lot of discomfort, while in the manipulation of omentum, bowels, and ovary, the pain was not notable ${ }^{26}$.

An additional use of the micro- laparoscopy consists of the preliminary visualization of the umbilical region in patients with extensive previous abdominal surgeries. In these cases, a microlaparoscope could be introduced in the left hypochondrium (Palmer point) to verify the presence of adhesions in the umbilical area. If possible, the lysis could be accomplished by introducing the traditional forceps into the iliac fossas ${ }^{15}$.

With microlaparoscopy, there has been a reduction in surgical complications due to the possibility of visualizing the abdominal cavity before the pneumoperitoneum is installed, avoiding the insufflation of erroneous places such as the subcutaneous layer or retroperitoneum ${ }^{9}$. Incisional herniations are rare since the cannula is smaller ${ }^{11}$. With the reduction of the pneumoperitoneum pressure, a smaller amount of carbonic gas is utilized, which prevents the pain in the shoulder that is usually experienced in conventional laparoscopies. In the patients included in this study, there were no surgical complications, and none of the patients complained about pain in the scapula in the postoperative period.

As a disadvantage of this method, microlaparoscopy requires new training even for the experienced laparoscopic surgeons because there is a 30 to $40 \%$ reduction of the skill using the 2-mm instruments ${ }^{18}$. When compared with traditional laparoscopy using a 10-mm telescope, microlaparoscopy offers a $40 \%$ smaller visual field, making it more difficult to centralize and focalize the image ${ }^{12,23}$. Additionally, the instruments are more delicate and require adequate skill to operate.

Probably in the near future, microlaparoscopy will be a routinely used technique for endoscopic procedures. Nowadays, this method represents an interesting alternative to some easier interventions, and the simplification of anesthesia may still bring more benefits, drastically reducing the socioeconomic and psychologic costs of surgical procedures. 
IKEDA F e col. - Microlaparoscopia em ginecologia: análise de 16 casos e revisão da literatura. Rev. Hosp. Clín. Fac. Med. S. Paulo 56(4): 115-118, 2001.

A microlaparoscopia representa a evolução da cirurgia endoscópica, visando um procedimento cirúrgico minimamente invasivo. As suas vantagens incluem a redução das complicações cirúrgicas, retorno às atividades mais rápido, período pós-operatório mais confortável e resultado estético satisfatório. A possibilidade da realização sob sedação pode resultar em internação hospitalar menor, diminuição dos custos hospitalares, além da simplificação do procedimento anestésico.

Os autores relatam sua experiência inicial com a microlaparoscopia, utilizando óptica e instrumentais de $2 \mathrm{~mm}$, assim como uma revisão dos trabalhos publicados desde a introdução dessa nova técnica. $\mathrm{O}$ relato destes 16 casos mostrou ser a microlaparoscopia exeqüível, apresentando resultados satisfatórios. Por outro lado, o seu uso requer indicações precisas e treinamento para manipular o instrumental.

DESCRITORES: Laparoscopia. Ginecologia. Microcirurgia. Procedimentos Cirúrgicos.

\section{REFERENCES}

1. ABRÃO MS \& IKEDA F - O impacto da laparoscopia no diagnóstico da endometriose. In: ABRÃO MS, editor. Endometriose: uma visão contemporânea. São Paulo, Revinter, 2000. p.111-125.

2. ABRÃO MS, IKEDA F, PODGAEC S et al. - Microlaparoscopy for an intact ectopic pregnancy and endometriosis with the use of a diode laser. Hum Reprod 2000; 15(6):1369-1371.

3. ALMEIDA OD Jr \& VAL-GALLAS JM - Office microlaparoscopy under local anaesthesia in the diagnosis and treatment of chronic pelvic pain. J Am Assoc Gynecol Laparosc 1998; 5 (4): 407-410.

4. ALMEIDA OD Jr, VAL-GALLAS JM \& RISK B - Appendectomy under local anaesthesia following conscious pain mapping with microlaparoscopy. Hum Reprod 1998; 13(3):588-590.

5. AMERICAN society for reproductive medicine - Revised American Society for Reproductive Medicine classification of endometriosis: 1996. Fertil Steril 1997; 67(5):817-821.

6. BAUER O, DEVROEY P, WISANTO A et al. - Small diameter laparoscopy using a microlaparoscope. Hum Reprod 1995; 10(6):1461-1464

7. CASTELLOTTI DS, MOTTA ELA, ALEGRETTI JR et al. - Successful birth after intrafallopian transfer of microhatched embryos. Fertil Steril 1997; 68(2):367-369.

8. DORSEY JM \& TABB CR - Mini-laparoscopy and fiber optic lasers. Obstet Gynecol Clin North Am 1991; 18:613-617.

9. DOWNING BG \& WOOD C - Initial experience with a new microlaparoscope $2 \mathrm{~mm}$ in external diameter. Aust $\mathbf{N}$ Z Obstet Gynaecol 1995; 35(2):202-204.

10. FABER BM \& CODDINGTON CC - Microlaparoscopy: a comparative study of diagnostic accuracy. Fertil Steril 1997; 67(5):952-954.

11. FULLER PN - Microendoscopic surgery: A comparison of four microendoscopes and a review of the literature. Am J Obstet Gynecol 1996; 174:1757-1762.

12. HAEUSLER G, LEHNER R, HANZAL E et al. - Diagnostic accuracy of $2 \mathrm{~mm}$ microlaparoscopy. Acta Obstet Gynecol Scand 1996; 75:672-675.

13. HELVACIOGLU A \& WEIS R - Operative laparoscopy and postoperative pain relief. Fertil Steril 1992; 57(3):548-552.

14. KOVACS GT, BAKER G, DILON M et al. - The microlaparoscope should be used routinely for diagnostic laparoscopy. Fertil Steril 1998; 70(4):698-701.

15.LEE PI, CHI YS, CHANG YK et al. - Minilaparoscopy to reduce complications from cannula insertion in patients with previous pelvic or abdominal surgery. J Am Assoc Gynecol Laparosc 1999; 6(1):91-95.

16. MOLLOY D - The diagnostic accuracy of a microlaparoscope. J Am Assoc Gynecol Laparosc 1995; 2(2):203-206.

17. NEZHAT C, NEZHAT F \& NEZHAT C - Laparoscopia Operatória (Cirurgia Minimamente Invasiva): Estado de Conhecimento. In: UENO J, editor. Cirurgia Video-endoscópica em Ginecologia. São Paulo, Roca, 1996. p. 247-70.

18. PALTER SF - Office microlaparoscopy under local anesthesia. Obstet Gynecol Clin North Am 1999; 26(1):109-120.

19. PALTER SF \& OLIVE DL - Office microlaparoscopy under local anesthesia for chronic pelvic pain. J Am Assoc Gynecol Laparosc 1996; 3(3):359-364.

20. PELLICANO M, ZULLO F, DI CARLO C et al. - Postoperative pain control after microlaparoscopy in patients with infertility: a prospective randomized study. Fertil Steril 1998; 70(2):289-292.

21. RISQUEZ F, PENNEHOUAT G, FERNANDEZ R et al. - Microlaparoscopy: a preliminary report. Hum Reprod 1993; 8(10):1701-1702.

22. RISQUEZ F, PENNEHOUAT G, FOULOT H et al. - Transcervical tubal cannulation and falloposcopy for the management of tubal pregnancy. Hum Reprod 1992; 7:375-376.

23. RISQUEZ F, PENNEHOUAT G, MC CORVEY R et al. - Diagnostic and operative microlaparoscopy: a preliminary multicentre report. Hum Reprod 1997; 12(8):1645-1648.

24. STEELE SJ - The potential for improved abdominal procedures and approaches for tubal occlusion. Int J Gynaecol Obstet 1995; 51(Suppl 1):S17-S22.

25. WATTIEZ A, GOLDCHMIT R, DURRUTY G et al. - Minilaparoscopy hysterectomy. J Am Assoc Gynecol Laparosc 1999; 5(4):97-100.

26. ZUPI E, SBRACIA M, MARCONI D et al. - Pain mapping during minilaparoscopy in infertile patients without pathology. J Am Assoc Gynecol Laparosc 1999; 6(1):51-4.

Received for publication on December 12, 2000 